\title{
The neoliberal (il)legitimacy of the duty of loyalty
}

\author{
Daniel AtTenborough
}

University of Leicester

\begin{abstract}
$\underline{\text { Abstract }}$
The reformulated duty of loyalty now found in s 172 of the Companies Act 2006 has been seen as imprecise or an ambiguous development for directors' duties. It has generated debate about what is the best reading of the duty, the most fundamental aspect of which is whether this behavioural standard obliges a narrow focus on financial capital or a broader notion of well-being and inclusiveness amongst nonshareholder interests. This article argues that the law as a privileged and constitutive way of society-making can only be understood within a broader conceptual framework rather than the more traditional expository analysis of law. The context in which such an analysis takes place is that of the anti-collectivist, marketbased political project of neoliberalsm. When viewed through this explanatory lens, we see very clearly that English legal doctrine codifies an embedded relationship between managers and shareholders. In doing so, the article shows that the extraction of private benefits of control by shareholders is not an inevitable occurrence, but a decades-long, human-created and contingent phenomenon. While non-shareholder interests are introduced into the duty, this precatory element is merely a potential source of legitimacy to the ideology of the company as a private, exclusively shareholder-oriented enterprise.
\end{abstract}

\section{Introduction}

A newspaper cartoon from the middle of the twentieth century depicts a US senator Atelling his colleagues, 'I admit this new Bill is too complicated to understand. We will just have to pass it to find out what it means." ${ }^{1}$ The meaningfulness of this satirical reflection on the very real difficulties inherent in the reading of legislation might be said to find expression in the recent statement of seven codified general duties that are imposed on company directors found in ch 2 of pt 10 of the Companies Act 2006. Prior to the enactment of the 2006 Act the behavioural standards expected of corporate management were instantiated in a highly problematic regulatory mixture of common law rules and equitable principles. The vanguard of this new statutory scheme of obligations is the reformulated duty of loyalty now found in s 172, which determines the propriety of directorial conduct under all the subsequent duties. It follows that it has the potential to

* Senior lecturer in law, University of Leicester. The author wishes to thank Andrew Keay, Ernest Lim, Marc Moore and Paul O'Connell for extremely helpful comments and suggestions on earlier versions of this article. The usual disclaimers apply.

1 This example is provided in F Frankfurter, 'Some Reflections on the Reading of Statutes' (1947) 47 Columbia Law Review 527, 545. 
provide some guidance for directors in the carrying out of their other functions. More fundamental still is that the framing of the duty of loyalty is said to endorse and enshrine the animating idea of enlightened shareholder value, which was of central importance to the company law reform project. ${ }^{2}$ This principle is related to corporate governance as it provides for how public or private companies are to be managed in the realisation of chosen organisational objectives.

Naturally enough, the effect of introducing a prescribed code of behaviour for directors is to throw the law into a period of uncertainty as to its best reading, based on the difficulties inherent in the nature of language used, of composition and of legislation generally. ${ }^{3}$ Many open issues remain about how the courts will apply the reformulated duty of loyalty, the most fundamental of which involve whether this behavioural standard merely replicates the common law position or represents a more radical departure from the traditional conception of the duty. Additionally, the duty explicitly suggests a highly subjective compliance test that requires a director to act in the way he or she considers, in good faith, to be most likely to promote the success of the company for the benefit of the members as a whole. Consequently, there would appear to be no definite standard against which to evaluate the propriety of any given decision. Taken as a whole, it is difficult to anticipate how the operation of the individual components of the duty will work in practice. A problem in statutory construction can seriously trouble the courts when there is a contest between probabilities of meaning. Legal academics and practitioners have thus fervently spent a considerable portion of time reading, discussing and producing interpretations and evaluations of the best reading of s 172. This dialogue has often in various ways involved reference to the Company Law Review reports and ministerial debates in order to ascertain the purpose of economic organisation. ${ }^{4}$ However, there has been up to this point only hidden or half-articulated discussion on how corporate governance operates in the context of major ideological and institutional processes. This unsatisfactory understanding of how these rules function in the context of extraneous bias and distortion, and the profound effect this can have on law-making, constitutes a significant lacuna in our understanding of the law that this article seeks to fill.

This article argues that the highly subjective nature of the duty can be likened without any great inaccuracy to the originating judicially formulated standard of review that enabled directors' good faith judgement to render their legal obligations according to situational expectations. It is submitted that this purported continuity of the statutory version, however, necessarily operates within the context of all forms of law as social practices. In other words, the subjective nature of the duty and how it is interpreted will be given meaning by the overlaying cultural, ideological and practical context that organisational activity gives rise to. It is thus essential to read the reformulated duty within a broader conceptual framework rather than the more traditional approach of substantive black

2 J Lowry, 'The Duty of Loyalty of Company Directors: Bridging the Accountability Gap through Efficient Disclosure' (2009) 68 Cambridge Law Journal 607, 608, describing the review as 'the most far-reaching review of company law since Gladstone's Joint Stock Companies Act 1844 and the introduction of Limited Liability in $1855^{\prime}$.

3 H R Hahlo, 'Here Lies the Common Law: Rest in Peace' (1967) 30 Modern Law Review 241, 249, remarking that, ' $[\mathrm{t}]$ he immediate effect of the introduction of a code, so far from making the law more certain, is to create a lengthy period of uncertainty'. See also, Lord Hoffmann, 'Fifth John Lehane Memorial Lecture: The Influence of European Law on the Common Law in English Courts', 18 August 2010, Sydney, Australia, para 12 <www.allens.com.au/pubs/pdf/paplehane10.pdf> accessed 27 August 2013; Lord Hoffman in $A v$ Secretary of State for the Home Department [2004] UKHL 56; [2005] 2 AC 68, [88].

4 On the measured use of legislative history in statutory interpretation, see Pepper $v$ Hart [1992] UKHL 3. For academic criticism, see A Kavanagh, 'Pepper v Hart and Matters of Constitutional Principle' (2005) Law Quarterly Review 98. 
letter' or 'expository' analysis of law. Central to this understanding is that the canons of statutory interpretation have a place, but it is secondary, after elucidation of more fundamental issues concerning law as a privileged and constitutive way of society-making. The significant explanatory power of this lens draws our attention to the way in which distinct regulatory choices, which are driven by distinct policy preferences, form the law and the application of that law. So, the article explores the strength of the case for corporate governance to be understood as a systemic process which is determined mostly in accordance with prevailing institutional arrangements that lie largely outside the corporate organisation and the parameters of company law.

The prevailing context in which these institutional arrangements find expression, it will be argued, is that of a globalised, interconnected and interdependent world, the defining characteristics of which are the anti-collectivist, market-based political project of neoliberalism and short-term equity market imperatives of financial capitalism. If we look inside the new statutory reformulation of the duty, we see very clearly that it enshrines and endorses a strongly oriented shareholder prerogative. The genesis of this avowedly narrow duty of loyalty has its origins in the Company Law Review's expressed ideological presumption against interventionist legislation and in favour of facilitating markets. ${ }^{5}$ It is these ideological pressures and the globalisation of product and financial markets, it is submitted, which mandate a consensus on the shareholder-oriented model of the company. ${ }^{6}$ This is despite the fact that English legal doctrine has hitherto never provided unequivocal credence to this position. ${ }^{7}$ Neoliberal thinking as a discipline-shaping phenomenon influences not only the role and expectations of most shareholders, ${ }^{8}$ but also the corporate organisation and the architecture of company law. Although there is an expectation in the UK and in Europe generally that shareholders should behave responsibly, ${ }^{9}$ neoliberalism allows shareholders the freedom to necessarily possess shortterm, profit-maximising goals that lead them to seek out the highest returns in a global economy. ${ }^{10}$ This legal myopia precludes the moral choice of harmonising the interests of

5 Company Law Review, Modern Company Law for a Competitive Economy: Strategic Framework (Department of Trade and Industry 1999) paras 2.1-2.34. On this issue, see S Worthington, 'Reforming Directors' Duties' (2001) 64(3) Modern Law Review 439, 443.

6 H Hansmann and R Kraakman, 'The End of History for Corporate Law' (2001) 89 Georgetown Law Journal 439, 468 .

7 M Moore and A Rebérioux, 'Revitalising the Institutional Roots of Anglo-American Corporate Governance' (2011) 40 Economy and Society $84,86$.

8 Of course, even though shareholders set the 'rules of the game' through corporate contractual arrangements and proprietary claims of capital, it must be acknowledged that there will likely be some variance between the expectations of shareholders according to the type of company, particular organisational objectives etc. See D Attenborough, 'Enforcement of Corporate Conduct under the Equitable Maximisation and Viability Principle' (2013) 33(4) Legal Studies 650, 651, observing that: '[t]he context and structure of corporate law mean that a myriad of institutions can be established and operated for diverse purposes, with the corporate constitution often stating the substantive aims for which it has been registered. These written constitutional objectives may, in turn, be significantly different for commercial, as opposed to not-for-profit, organisations and even amongst the spectrum of profit making entities. In this sense, it is impossible for intellectual endeavour to prescribe such a construct as "a" corporate purpose or objective that related to existing facultative corporate law or that law generally.'

9 A Dignam, 'The Future of Shareholder Democracy in the Shadow of the Financial Crisis' (2013) 36 Seattle University Law Review 639, 690. Dignam refers to the Companies Act 2006 preferring the term members rather than shareholders to describe equity holders. He goes on to suggest astutely that, ' $[\mathrm{m}] \mathrm{ember}$ probably more accurately conveys the expectation that we have for shareholders to participate in the corporation, abide by the rules, and behave responsibly. We assume at the policy level that shareholders want to be good, if only they could. And if they are not, there must be some technical impediment to unleashing their goodness.'

10 L Talbot, 'Why Shareholders Shouldn't Vote: A Marxist-progressive Critique of Shareholder Empowerment' (2013) 76 Modern Law Review 791, 793. 
shareholders with the interests of a host of other corporate participants. Viewed this way, the introduction of non-shareholder interests into the statutory lexicon might be best read as a precatory aspect of the duty that dissolves notions of distributional fairness. Indeed, it is argued that statutory provision for non-shareholder interests is a potential source of legitimacy to 'an implicit alliance between managers and investors'. ${ }^{11}$

The article will not, quite, be attempting to answer the question, analytically and empirically, of whether the integration of non-shareholder interests into the management calculus should mean a concomitant downgrading of the presumptive imperatives of private capital-owning investors - much less whether it is desirable enough to warrant a radical revision of English company law. It will be satisfactory if the article can provide a clarifying vantage point from which to approach the particular legislative reform of the duty of loyalty in companies. This article proceeds in four stages. Initially, section 2 outlines neoliberalism and financialised capitalism in broad terms and only to the extent necessary to explain a primary concern in section 3 of this paper - that is, how a broad social theory can help us to understand and explain s 172 as well as to assess why the logic and language of these ideologies are antagonistic to the concept of 'enlightened' corporate performance. Section 4 provides a more detailed examination of the two aspects comprising the reformulated duty of loyalty. In doing so, it provides a more favourable interpretation of the provision which disperses any legislative ambiguities and makes a compelling case for how the Act is to be read. Section 5 provides some concluding remarks.

\section{Neoliberalism and financialised capitalism}

This section of the article considers the emergence of the neoliberal economic order. The aim is not to provide a comprehensive analysis of neoliberalism. There are many interesting issues in this regard, but they have been addressed extensively elsewhere. ${ }^{12}$ The ideology is outlined in preliminary terms and only to the extent necessary to explain a primary concern of this paper - that is, how the key to understanding s 172 is to be found in the hegemonic influence of neoliberalism on ways of thought and political-economic practices everywhere since the 1970s. The proposition that the law does not exist in a vacuum would today scarcely be an exciting truth. The notion that no aspect of law can be understood unless it is seen within the perspective of a broader social theory or political philosophy surely has been commonplace for at least a century. ${ }^{13}$ William Twining has said of understanding legal rules that in order to understand law in the world today it is more important than ever to reorientate and engage with epistemology to reach the realities of all forms of law as social practices. ${ }^{14}$ This, in Karl Llewellyn's words, is 'to see it whole'. ${ }^{15}$ It is a truism that we are, to some extent, creatures of our time and space. Of course, the context in which such an analysis takes place is that of a globalised, interconnected and interdependent world.

11 R Boyer, 'From Shareholder Value to CEO Power: The Paradox of the 1990s' (2005) 9 Competition and Change $7,21$.

12 For general discussion, see N Chomsky, Profit Over People: Neoliberalism and Global Order (Seven Stories Press 1998); D Harvey, A Brief History of Neoliberalism (OUP 2007); S L Mudge, 'What is Neoliberalism?' (2008) 6 Socio-Economic Review 703; R Plant, The Neoliberal State (OUP 2010). For a classic critique of some form of nascent neoliberalism brought about following the end of the Second World War, see K Polanyi, The Great Transformation: The Political and Economic Origins of Our Time (2nd edn Beacon Press 2002).

13 The intellectual heritage of such Western jurisprudence contains a large number of 'accredited schools', with legions of scholars competing to articulate their favourite critical thesis or approach: positivism, natural law, law and economics, neo-Marxism, critical legal studies, feminist theories, critical race theory, legal pluralism and so on.

14 W Twining, General Jurisprudence: Understanding Law from a Global Perspective (CUP 2009) 7.

15 K Llewellyn, The Common Law Tradition: Deciding Appeals (Little, Brown \& Co 1960) 508-20. 
Globalisation is the underlying structural dynamic that drives social, political, economic and cultural ideological processes around the world in the twenty-first century. ${ }^{16} \mathrm{~A}$ defining characteristic of globalisation is well articulated by David Harvey, who observes that, since the 1970s, '[d]eregulation, privatisation, and withdrawal of the state from many areas of social provision have been all too common. Almost all states ... have embraced, sometimes voluntarily and in other instances in response to coercive pressures, some version of neoliberal theory and adjusted at least some policies and practices accordingly. ${ }^{17}$ The contemporary era has, as we shall see, been fundamentally driven by the definite political project of neoliberalism.

Neoliberalism has been transformed from a set of embryonic antecedents, ${ }^{18}$ ostensibly driven by an efficiently distributive thought collective ${ }^{19}$ as well as the forces of globalisation, to become a forceful and entrenched political project over recent decades in nearly all parts of the world. The ideology has not only become hegemonic among mainstream thinkers and political elites in the UK and USA but has also had a major impact on legal policy and the way we think about law. ${ }^{20}$ The ideology, of necessity, carries with it very definite understandings of the way we as a society inhabit and understand the world, notably an institutionalised and unquestioning cognitive adherence to standard neoclassical economics. ${ }^{21}$ Neoliberalism proposes, at least at the discursive level, that a necessary condition for human well-being is the maximisation of entrepreneurial freedoms within an institutional framework characterised by private property rights of ownership, individualism, wholly unregulated markets and free trade. ${ }^{22} \mathrm{~A}$ discipline-shaping set of shared ideological precepts articulate a vision of the free society in which economic rationality of the markets is the optimal way of organising economic activity because they are self-correcting, associated with competition, optimum economic efficiency and choice. This relates to company law in at least one central way insofar as '[a] totally unfettered market for corporate control is literally all that is needed for near ideal corporate

16 W I Robinson, A Theory of Global Capitalism: Production, Class, and State in a Transnational World (John Hopkins University Press 2004) xv.

17 Harvey (n 12) 3. See also, J Dragsbaek Schmidt and J Hersh, 'Neoliberal Globalization: Workforce Without Welfare' (2006) 3 Globalizations 69, 69. It should be noted, however, that a multitude of partial, divergent and often contradictory claims surround the contested concept of globalisation. On this, see J A Scholte, Globalization: A Critical Introduction (Palgrave 2005) $15 \mathrm{ff}$.

18 R S Turner, 'The Rebirth of Liberalism: The Origins of Neoliberal Ideology' (2007) 12 Journal of Political Ideologies 67 . Here, the author traces back to the 1940 s the genesis of neoliberalism as well as specifying the efforts to revive and redefine classical liberalism as a mainstream political ideology. See also, D Kotz, 'Neoliberalism and the US Economic Expansion of the 90s' (2003) 54 Monthly Review 15, 15, submitting that neoliberalism is an updated and more extreme version of the 'classical liberal' economic theory developed in the eighteenth and nineteenth centuries by Adam Smith and David Ricardo, who argued that a capitalist economy is largely self-regulating through the action of market forces.

19 B Jackson, 'At the Origins of Neoliberalism: The Free Economy and the Strong State, 1930-1947' (2010) 53 Historical Journal 129, 129-30.

20 P Ireland, 'Law and the Neoliberal Vision: Financial Property, Pension Privatisation and the Ownership Society' (2011) 62(1) Northern Ireland Law Quarterly 1, 2.

21 J L Campbell and O K Pederson (eds), The Rise of Neoliberalism and Institutional Analysis (Princeton University Press 2001) 5 .

22 Harvey (n 12) 5. On the seductive rhetoric of neoliberalism, Harvey posits that '[a] conceptual apparatus has to be advanced that appeals to our intuitions and instincts, to our values and our desires, as well as to the possibilities inherent in the social world we inhabit. If successful, this conceptual apparatus becomes so embedded in common sense as to be taken for granted and not open to question.' See also, Polanyi (n 12) 266, making the insightful point that this form of thinking envisages 'a market view of society which equate[s] economics with contractual relationships, and contractual relations with freedom'. 
governance'. ${ }^{23}$ The influence of these markets in disciplining and incentivising corporate directors, of course, includes the usual competitive pressures found in relevant product and services markets as well as capital markets and the market for executive talent. ${ }^{24}$ This 'free' market metaphor is deeply embedded in Anglo-American culture; 25 an autonomous market that is constrained only by competition, so we are told, ensures that individual rational actors navigating anonymous market signals and making optimal decisions in the allocation of capital and the pursuit of self-interested gain maximises overall social well-being. The role of the state is rendered as rent-seeking, inefficient and restrictive. It is, thus, an ideology that works to "displace political sovereignty with the sovereignty of "the market", as if the latter had a mind and morality of its own'. ${ }^{26}$ The very recourse to markets and the private sector would appear to eviscerate the importance of law and regulation, or even render it unnecessary. ${ }^{27}$

However plausible the intellectual efforts might appear, the actual political-economic policies and practices of neoliberalism frequently diverge from this ideological narrative. As Paddy Ireland has argued convincingly, 'you simply cannot understand the changes in the global financial markets since the early 1970s in terms of deregulation'. ${ }^{28}$ Ireland goes on to observe that 'markets are legal, political (and, therefore, regulatory) products, not spontaneously arising, pre-regulatory, pre-legal and pre-political phenomena'. ${ }^{29}$ In other words, not all corporate legal jurists are, or at least ought to be, trapped within this paradigm of a 'rolling back of the state' when it comes to the UK commercial legal landscape. In particular, the crude discourse frequently conducted through the prism of simplistic opposites of state versus market, it is argued, does not in fact accurately reflect the presence of an active, often activist, and sometimes violent, regulatory state in most neoliberal

23 H Manne, 'Corporate Governance: Getting Back to Market Basics' paper to Seminario Consob <www.consob.it/documenti/Pubblicazioni/Convegni_seminari/seminario_20081110_manne.pdf> accessed 27 August 2013.

24 L Johnson, 'Corporate Law Professors as Gatekeepers' (2009) 6(2) University of St Thomas Law Journal 447, 448.

25 On the naturalisation of expressions of neoliberal ideology, see Harvey (n 12) 5-6. The author suggests that: '[f]or any system of thought to become dominant, a conceptual apparatus has to be advanced that appeals to our intuitions and instincts, to our values and our desires, as well as to the possibilities inherent in the social world we inhabit. If successful, this conceptual apparatus becomes so embedded in common sense as to be taken for granted and not open to questions. The founding figures of neoliberal thought took political ideals of human dignity and individual freedom as fundamental.' On the wider capture of state and society (media, politics, academia), see O Visser and D Kalb, 'Financialised Capitalism Soviet Style? Varieties of State Capture and Crisis' (2010) 51 European Journal of Sociology 171, 188, observing that: '[s]igns of the fundamental flaws of the system [are] presented as instances of deplorable individual greed, moral hazard, fraud or corruption and [are] pictured as exceptional excesses that [should] be punished. It [leaves] the status quo largely undisputed.'

26 J Comaroff and J L Comaroff, Millennial Capitalism: First Thoughts on a Second Coming (Duke University Press 2001) 333.

27 A C Aman, 'Law, Markets and Democracy: A Role for Law in the Neoliberal State' (2006) 51 New York Law School Review 802, 809.

28 Ireland (n 20) 15.

29 Ibid 29. 
varieties of capitalism. ${ }^{30}$ It follows that it is partial and therefore misleading to focus any corporate governance discussion on the minimal state as well as public intervention as a negative of the market. In the final analysis, the responsibility for promoting neoliberalism as a political project remains with individual nation states; so any given state is not typically a neutral policymaker in relation to aspects of the corporate organisation and the limits of company law. It is instead submitted that the purest conception of neoliberal practice is that it 'was never about total withdrawal of the state; it was about a qualitative restructuring of the state, involving not so much less state intervention as a different kind of state intervention [my emphasis added]'. 31 Hutchinson and Jones, equally, have asserted that it is never a matter of whether the state should act, but exactly when and how it should regulate social life and economic activity. ${ }^{32}$ The central insight is that the state is not, as some suggest, external or involuntarily relinquishing sovereignty, ${ }^{33}$ but is a state that purposefully establishes and preserves through constant action an artificial institutional framework appropriate to such competitive practices. ${ }^{34}$ If markets do not exist, then they must be created or reconfigured, by state action if necessary. But beyond these efforts the state should stay out of the economy, including corporate affairs.

Neoliberal restructuring, then, is a type of regulatory capture which focuses on reorienting the role of the state in the introduction, implementation and reproduction of neoliberalsm. Since the 1970s the neoliberal, globalised economy has been typically associated with privatisation, commercialisation and commodification, with the aim of privileging and intensifying the conditions necessary for profit-making and to form a framework for private capital accumulation. ${ }^{35}$ In order to encourage an institutional framework within which the market-based logic can operate, there needs to be a removal of impediments to free

30 D Campbell, 'Review Article: The End of Posnerian Law and Economics' (2010) 73 Modern Law Review 305 , 326, unrestrainedly observing that: '[n]o market . . can conform to the assumptions of fully contingent contracting, nor exist free of regulation, and so full deregulation is an absurd goal of economic policy'. See also Ireland (n 20) 23, noting that '[n]eoliberalism has indeed entailed some deregulation, not least in the financial sphere, but, in general, what we have seen in recent decades is not so much a retreat as a major change in the nature and forms of state activity. In many spheres, there has been a marked increase in interventionism, not only by states but by international agencies, much of it . . directed at creating "good climates for investment". The financial crisis occurred in a heavily regulated world and those who seek to understand the neoliberal era only at the ideological level, in terms of its self-professed determination to free markets from states, will struggle to make sense of actual neoliberal practice.'; Polanyi (n 12) 258, writing that '[e]conomic history reveals that ... the market has been the outcome of a conscious and often violent intervention on the part of government which imposed the market organization on society for noneconomic ends'.

31 M B Aalbers, 'Neoliberalism is Dead . . Long Live Neoliberalism' (2013) 37 International Journal of Urban and Regional Research 1083, 1084. See also, D Cahill, 'Actually Existing Neoliberalism and the Global Financial Crisis' (2010) 20 Labour and History 298, 300.

32 A Hutchinson and M Jones, 'Wheeler Dealing: An Essay on Law, Politics, and Speech' (1988) 15 Journal of Law and Society 263, 274.

33 A Dignam and M Galanis, 'Corporate Governance and the Importance of Macroeconomic Context' (2008) 28 Oxford Journal of Legal Studies 201, 206, who posit that global macro-economic conditions may precipitate an unavoidable loss of governmental sovereignty with regard to choice of corporate governance system. See also, I Ramonet, 'Disarming the Market' Le Monde diplomatique (Paris December 1997) <http://mondediplo.com/1997/12/leader> accessed 28 October 2014, remarking that: 'Financial globalization is a law unto itself and it has established a separate supranational state with its own administrative apparatus, its own spheres of influence, its own means of action. That is to say, the International Monetary Fund (IMF), the World Bank, the Organization of Economic Cooperation and Development (OECD) and the World Trade Organization (WTO) . . This artificial state is a power with no base in society. It is answerable instead to the financial markets and the mammoth business undertakings that are its masters. The result is that the real states in the real world are becoming societies with no power base.'

34 Harvey (n 12) 2. See also, B Amable, 'Morals and Politics in the Ideology of Neoliberalism' (2011) 9 SocioEconomic Review 3, 10.

35 Talbot (n 10) especially 793. 
movements of goods, services and especially capital, throughout the global economy. In the context of economic globalisation the establishment of the centrality of the global market has thus required voluminous rules and institutions to loosen or eliminate government regulation of corporate behaviour in both domestic and international spheres; renouncing the use of government spending and taxing to moderate the instability of the business cycle; privatisation of government enterprises and public responsibilities; and large cutbacks in state social programmes. ${ }^{36}$ The result of these and other changes to the structural parameters of commerce, including those effected through law, has been a diminished role for the board of directors, a marked redistribution of the proceeds of industry from labour to the shareowning class and to small elites in industry and finance, downward pressure on wages, and a sharp reversal of the trend towards greater equality. 37 However efficient the market is purported to be at setting prices, ${ }^{38}$ it cannot be relied upon to ensure that commerce will always act in the interests of society. ${ }^{39}$ Indeed, what it does is divide the population into two branches: those with economic power and those without it. Naturally enough, the latter group is much larger in almost all societies. So the central issue here is the gulf between that which is conceptually possible and that which is realisable given the distribution of power and interests in society. The neoliberal worldview is, thus, likely to be antagonistic to a new ethic of the company as a social institution rather than a private enterprise.

What is uniquely characteristic of the current period of neoliberalism is the extraordinary extent to which the specific embedding of finance has been both deepened and broadened. Such developments have within the literature been best captured by the notion of financialisation. It is, directly or otherwise, the subject of all the literature on neoliberalism, globalisation and stabilisation. Although a recent, still ill-defined term, financialisation can be taken to mean, in essence, the ongoing and increasing role of financial motives and the extension and growth of 'liberalised' financial markets, financial actors and financial institutions in the operation of the domestic and international economies. ${ }^{40}$ This economic order is one in which the financial markets exist primarily to serve themselves. In this system, capital is raised for the purpose of creating, selling and

36 Kotz (n 18) 15. See also, A Dignam, 'Lamenting Reform? The Changing Nature of Common Law Corporate Governance Regulation' (2007) 25 Company and Securities Law Journal 283, 285, observing that: 'Margaret Thatcher's admiration of free market economists . . . soon had the UK engaging in wholesale reform of its public sector based upon market solutions. The privatisation of public sector industries (Telecoms, Gas, Water, Electricity, etc.), reform of pension provision, health care, social welfare, the removal of barriers to capital inflow and outflows and the removal of employment protection changed the nature of the corporate governance debate utterly within the course of a decade. Government policy changed from giving priority to creating employment to a focus on economic tools such as interest rate levels which could keep capital flowing into the UK. Industrial democracy was replaced by shareholder oriented market based solutions.'

37 Ireland (n 20) 24.

38 On the subject of share prices failing to adjust rapidly to new information, see S Bhagat and R Romano, 'Event Studies and the Law: Part I - Technique and Corporate Litigation' (2002) 4 American Law and Economics Review 141, 143. On the fact that it cannot be taken for granted that share prices are a reliable indicator of corporate value, see A Shleifer, Inefficient Markets: An Introduction to Behavioural Finance (OUP 2000) 178-84; L A Stout, 'Share Price as a Poor Criterion for Good Corporate Law' (2005) 3 Berkley Business Law Journal 43.

39 S B Banerjee, 'Corporate Social Responsibility: The Good, the Bad and the Ugly' (2008) 34 Critical Sociology 51, 74; M T Jones, 'Missing the Forest for the Trees' (1996) 35 Business and Society 7, 7; R J Arneson, 'Prospects for Community in a Market Economy' (1981) 9 Political Theory 207, 207, noting that one hallowed objection to a market economy is the supposed incapacity of a market to supply the good of the community; J E Stiglitz, 'Foreword' in Polanyi (n 12) viii, asserting that 'there is no respectable intellectual support for the proposition that markets, by themselves, lead to efficient, let alone equitable outcomes'.

40 G Krippner, 'The Financialization of the American Economy' (2005) 3 Socio-Economic Review 173, 174, describing it more succinctly as 'a pattern of accumulation in which profits accrue primarily through financial channels rather than through trade and commodity production'. 
trading securities and derivative securities that do not finance industry but instead trade within markets that exist as an economy unto themselves. ${ }^{41}$ The rising significance of (or increasing reliance on) financial capital in the global economy is, for some, central to the advancement of neoliberalism. ${ }^{42}$ As Duménil and Lévy put it, 'neoliberalism is the ideological expression of the reasserted power of finance'. ${ }^{3}$ The resurgence and continuing dominance of neoliberalism, so the argument goes, can be explained, at least in part, by changes in the competitive structure of world capitalism, which have resulted in turn from the particular form of global economic integration that has developed in recent decades. ${ }^{44}$ However, David Kotz astutely suggests that neoliberalism arose at the end of the 1970s for reasons not directly related to the process of financialisation. According to this view, financialisation is an ever-present tendency in corporate capitalism and, because of discrete neoliberal structural changes to release various constraints, it developed rapidly in the favourable neoliberal institutional context. David Harvey has similarly remarked that neoliberalism meant, in essence, the systematic financialisation of everything and the relocation of the power centre of capital accumulation to owners and their financial institutions at the expense of other factions of capital. For this reason, he argues, the support of financial institutions and the integrity of the financial system has become the central concern collectively of neoliberal states. ${ }^{45}$ It is submitted that these processes are most likely to be symbiotic; one supports the other and vice versa.

\section{Regulatory capture of legislative reform}

What is more certain is that the shift in gravity of organisational activity from an increasingly underinvested or obsolete productive base to the dysfunctional nature of finance-driven growth and financial interests ${ }^{46}$ denotes a new form of competition which has worked to 'reposition the shareholder at centre stage'. ${ }^{47}$ Indeed, for more than a decade now a recurrent dimension to UK and US academic writing has expounded the homogenising force of global finance, the neoliberal logic of which has assisted the reassertion of the shareholder-oriented conception of the company being constitutionalised and entrenched around the world by legal and extra-legal drivers. ${ }^{48}$ This divisive phenomenon is frequently referred to within the company law academy as the

41 L E Mitchell, 'Financialism: A (Very) Brief History' in C Williams and P Zumbansen (eds), The Embedded Firm: Corporate Governance, Labor, and Finance Capitalism (CUP 2011) 42.

42 Y Zhang and J Andrew, 'Financialization and the Conceptual Framework' (2013) Critical Perspectives on Accounting doi: 10.1016/j.cpa.2012.11.012.

43 G Duménil and D Lévy, 'Costs and Benefits of Neoliberalism: A Class Analysis' (2001) 8 Review of International Political Economy 578, 579.

44 D M Kotz, 'Globalization and Neoliberalism' (2002) 14 Rethinking Marxism 64, 65. See also, H A Giroux, 'The Terror of Neoliberalism: Rethinking the Significance of Cultural Politics' (2005) 32 College Literature 1, 2 , remarking that neoliberalism is a 'virulent and brutal form of market capitalism'.

45 Harvey (n 12) 73

46 F G Hill, 'Veblen, Berle and the Modern Corporation' (1967) 26 American Journal of Economics and Sociology 279, 281; Harvey (n 12) 32-3; J Froud, C Haslam, S Johal and K Williams, 'Shareholder Value and Financialization: Consultancy Promises, Management Moves' (2000) 29 Economy and Society 80, 103.

47 B D Merino, A G Mayper and T D Tolleston, 'Neoliberalism, Deregulation and Sarbanes-Oxley' (2010) 23 Accounting, Auditing and Accountability Journal 774, 777.

48 P Ireland and R G Pillay, 'Corporate Social Responsibility in a Neoliberal Age' in P Utting and J C Marques (eds), Corporate Social Responsibility and Regulatory Governance (Palgrave 2009) 91. 
shareholder value or shareholder primacy principle. ${ }^{49}$ It is generally regarded as applying in relation to companies located in common law jurisdictions. The principle typically denotes, in essence, the corporate managerial standard of generating an optimal (or at least relatively high) dividend or capital return from a company's business for the main benefit of its shareholders. ${ }^{50}$ The varieties of other stakeholders are to receive no inevitable primacy. ${ }^{51} \mathrm{It}$ is a convention that has been best captured by the Nobel laureate economist, Milton Friedman, writing at a time when neoliberalism as a political project was in its incipient stages, who influentially proclaimed that 'the [only] responsibility of business is to increase profits. ${ }^{52}$ It is easy for company lawyers to assume that managerial accountability to the shareholders is not, in essence, an absurd or pernicious concept. A board of directors, as Adam Smith (and those influenced by his writing) observed long ago, is charged with taking care of other people's money ${ }^{53}$ and it is usual in such circumstances for the law to impose special and unremitting duties. For many the UK-US legal model, so it follows, elevates an observable and measureable metric of shareholder value to the extent that investor interests have often been equated with corporate interests in this model of governance. These developments have prompted two US legal scholars, writing in 2001, to announce in somewhat of a provocative fashion, but not without some element of validity, that we had reached 'the end of history for corporate law'. ${ }^{4}$

Many legal scholars have criticised the shareholder value principle for a number of reasons - including its perceived unfairness to non-shareholders and its appropriateness as a touchstone for corporate governance - or questioned its doctrinal reflectivity. Contrary to conventional wisdom, this principle as a perceived legally sanctioned norm of managerial conduct has historically found expression to only a very limited extent in pre-existing UK or US legal rules. ${ }^{55}$ As Simon Deakin has said, '[i]t is surprisingly difficult to find support within company law for the notion of shareholder primacy. ${ }^{56}$ In English company law, the

49 For some of the leading works on the principle, see J R Macey, 'An Economic Analysis of the Various Rationales for Making Shareholders the Exclusive Beneficiaries of Corporate Fiduciary Duties’ (1991) 21 Stetson Law Review 23; S M Bainbridge, 'In Defense of the Shareholder Maximization Norm: A Reply to Professor Green' (1993) 50 Wash and Lee Law Review 1423; J Fisch 'Measuring Efficiency in Corporate Law: The Role of Shareholder Primary' (2006) Journal of Corporation Law 637; B Black and R Kraakman, 'A Self-enforcing Model of Corporate Law' (1996) 109 Harvard Law Review 1911; D Gordon Smith, 'The Shareholder Primacy Norm' (1998) 23 Journal of Corporation Law 277; R Grantham, 'The Doctrinal Basis of the Rights of Company Shareholders' (1998) 57(3) Cambridge Law Journal 554; C O'Kelly, 'History Begins: Shareholder Value, Accountability and the Virtuous State' (2009) 60 Northern Ireland Law Quarterly 35.

50 C Mayer, 'Corporate Governance, Competition and Performance' (1997) 24 Journal of Law and Society 152, 155.

51 This includes, but is not limited to, the company's employees, creditors and suppliers, surrounding environment and community, consumers etc.

52 M Friedman, 'The Social Responsibility of Business is to Increase its Profits' New York Times (New York 13 September 1970). A brief, but very useful deconstruction, of Friedman's purported views can be found in Johnson (n 24) 451-2.

53 A Smith, The Wealth of Nations (first published 1776, 5th edn Methuen \& Co 1904) pt 1, ch 2.

54 Hansmann and Kraakman (n 6). Although, Andrew Keay astutely observes that since this bold proclamation we have witnessed the collapse of Enron, Worldcom etc. and, more recently, the demise or emasculation of major banks such as Northern Rock in the UK and Lehman Brothers in the USA. All this has led to a greater degree of questioning the practical and normative value of the shareholder value principle. See A Keay, The Enlightened Shareholder Value Principle and Corporate Governance (Routledge 2012) 279.

55 See e.g. Moore and Rebérioux (n 7) 86; M Blair and L Stout, 'A Team Production Theory of Corporate Law' (1999) 85 Virginia Law Review 247.

56 S Deakin, 'The Coming Transformation of Shareholder Value' (2005) 13 Corporate Governance 11, 11, submitting that " $[\mathrm{i}] \mathrm{t}$ is surprisingly difficult to find support within company law for the notion of shareholder primacy'. 
reference point for determining to whom directors owed their loyalty has historically been found in Percival $v$ Wright. ${ }^{57}$ According to this decision, it was for the directors to decide, in good faith, on how best to promote the 'interests of the company' in which they were involved. In other words, directors were said in the case law to owe a duty of loyalty to the company itself, ${ }^{58}$ but not to any individual shareholders or other persons. However, the term 'interests of the company' has, unsurprisingly, been regarded as a purposefully or carelessly imprecise judicial construct. ${ }^{59}$ That is to say, the inherent generality of the terms used to express these obligations meant that they, in and of themselves, provided no immediate standard against which to measure the propriety or impropriety of a director's action in a particular case. The proverbial question of what a company's 'interest' entails has thus featured in a continuing substantial debate in English company law, perhaps above all else in the attitudes and opinions that are shaped in legal monographs, law review articles and law school classrooms, ${ }^{60}$ but also, to some extent, in the limited range of cases where it has been assumed the courts have attempted to impute some doctrinal meaning to the expression. ${ }^{61}$ In this regard, a slight number of English authorities have been purported to equate the interests of the company with that of the present and future shareholders and thus to demonstrate the doctrinal significance of the shareholder value principle. ${ }^{62}$ But these cases make reference to the principle only in obiter dicta, confine any such remarks to the individual case and do not directly address the issue of directors' duties, or the interests of the company has simply been measured from the perspective of the ex ante bargain among investors. ${ }^{63}$ It would appear that the US courts have also not been completely unequivocal

57 Percival v Wright [1902] $2 \mathrm{Ch}$ 421. See also, Multinational Gas and Petrochemical Co v Multinational Gas and Petrochemical Services Ltd [1983] Ch 258; Grove v Flavel (1986) 43 SASR 410, 417 (Jacobs J); Peskin v Anderson [2000] BCC 1110; affirmed [2000] EWCA Civ 326 (unreported, Court of Appeal, Simon Brown, Mummery and Latham LJJ, 14 December 2000).

58 This follows the seminal House of Lords case of Salomon v Salomon and Co Ltd [1897] AC 22 (HL). For a useful exposition of the entity doctrine, see M A Pickering, 'The Company as a Separate Legal Entity' (1968) 31 Modern Law Review 481, especially 511, describing the evolution of the company as a separate legal entity as 'one of the law's greatest contributions to business and commerce'.

59 D Prentice, 'Creditor's Interests and Directors' Duties' (1990) 10 Oxford Journal of Legal Studies 265, 273, referring to the expression as 'indeterminate'.

60 A Keay, 'Formulating a Framework for Directors' Duties to Creditors: An Entity Maximisation Approach' (2005) 64 Cambridge Law Journal 614, 616, accurately capturing the vagueness of the term in suggesting that "[w] hat is meant by "companies as a whole" is a vexed question, for it has been an extremely difficult phrase to interpret'.

61 As pointed out by Nourse LJ in Brady v Brady (1987) 3 BCC 535, 552, this is an expression that is oft used, but is rarely defined, and it is probably one of the most problematical expressions in company law. Although, see M Moore, Corporate Governance in the Shadow of the State (Hart 2013) 191 (and accompanying footnote), suggesting that English as well as US courts have been traditionally reluctant to articulate exactly what the pursuit of a company's 'interest' entails, 'preferring instead to reserve such matters for ex ante resolution by corporate contractors themselves'.

62 On the ostensible indications of shareholder value as an objective of companies in English law, see $R e$ Wincham Shipping (1878) LR 9 Ch D 322; Hutton v West Cork Railway Co (1883) 23 Ch D 654; Greenhalgh v Arderne Cinemas [1951] Ch 286; Park v Daily News Ltd (1962) Ch 927; Gaiman v National Association for Mental Health [1971] Ch 317; Brady v Brady (n 61).

63 For an excellent exposition of this point, see e.g. Moore and Rebérioux (n 7) 95-100. See also, Keay (n 54) 53-5. 
in their acceptance of shareholder value. ${ }^{64}$ It is thus possible to suggest that the substantive law in these two countries, unexpectedly, has been agnostic on the important question of management's principal general duty. ${ }^{65}$

Following a second line of legitimating argument, many corporate academics and practitioners would identify the source of the shareholder value principle as being the 'arsenal of governance powers' 66 that equity holders possess to shape the rules of corporate governance. ${ }^{67}$ It is important to recognise that this vantage point rests on a particular understanding of the formal significance of decision-making power for shareholders in the English or US legal model. These governance rights are considered to provide assurance that directors will not abuse the powers granted to them, thereby instilling confidence in investors that capital may be safely entrusted to companies controlled by centralised management. In respect of English law, most texts and commentaries ${ }^{68}$ point to the shareholder body retaining residual and ultimate decision-making authority through statute, case law and the shareholder approval requirements in the UK Listing Authority's Listing Rules in decision areas that appear to raise acute agency problems arising from a direct conflict of interests. For certain of these controls, shareholders are purported to have various fundamental instruction and veto or approval rights, among which are the right to vote on a limited number of end-game governance issues in a general meeting ${ }^{69}$ and the

64 The legal principle underlying US corporate governance, as enshrined in Delaware General Corporation Law, $\$ 141$, which is regarded as the most important state for company law, is that ' $t$ ] he business and affairs of every corporation . . . shall be managed by or under the direction of a board of directors'. Again, though, a slim number of authorities have equated the interests of the company with those of the shareholders. See Dodge $v$ Ford Motor Co, 170 NW 668, 684 (Mich, 1919); Revlon Inc v MacAndrews \& Forbes Holdings Inc, 506 A 2d 173, 179 (Del, 1986); Polk $v$ Good, 507 A 2d 531, 536 (Del, 1986). For academic comment on the ambivalence of US corporate law see, W T Allen, J B Jacobs and L E Strine, 'The Great Takeover Debate: A Meditation on Bridging the Conceptual Divide' (2002) 69 University of Chicago Law Review 147, 147; L A Stout, 'Why We Should Stop Teaching Dodge v Ford (2008) 3 Virginia Law and Business Review 163.

65 D G Baird and M T Henderson, 'Other People’s Money' (2008) 60 Stanford Law Review 1309, 1312, suggesting that '[p] eople should know better [than to] paint themselves into embarrassing corners trying to reaffirm the principle'.

66 C M Bruner, Corporate Governance in the Common Law World: The Political Foundations of Shareholder Power (CUP 2013) 29. On the shareholder empowerment debate, see the particularly interesting and opposing arguments contained in a special edition of the Harvard Law Review: L A Bebchuk, 'The Case for Increasing Shareholder Power' (2005) 118 Harvard Law Review 833; S Bainbridge, 'Director Primacy and Shareholder Disempowerment' (2006) 118 Harvard Law Review 1735.

67 M T Jones, 'The Institutional Determinants of Social Responsibility' (1999) 20 Journal of Business Ethics 163, 166, points out that: ' $[t]$ he intensely political nature of the hierarchical relations of the workplace are generally conceptualised through the property rights discourse. Thus, the fact that management constitutes the legal representation of ownership interests enables it to decide what's what in the firm; secondary stakeholders such as employees and communities have only tenuous legal status in terms of challenging managerial prerogative.'

68 D Kershaw, Company Law in Context: Texts and Materials (2nd edn OUP 2012) 189ff; P L Davies and S Worthington, Gower and Davies: The Principles of Modern Company Law (9th edn Sweet \& Maxwell 2012) 435ff. But see R Nolan, 'The Continuing Evolution of Shareholder Governance' (2006) 65 Cambridge Law Journal 92, 93, who advocates that the doctrinal rights of shareholders are manifested in companies legislation, while cases about shareholders' rights have only an 'interstitial function, clarifying and fleshing out the relevant legislation and corporate documentation'.

69 It is well established that UK directors, not shareholders, manage the business. See Companies Act 2006, Model Articles, regs 3-4; Automatic Self-Cleansing Filter Syndicate Co Ltdv Cuninghame [1906] 2 Ch 34; L Sealy and S Worthington, Cases and Materials in Company Law (OUP 2008) 167 and ch 4. For US examples, see, generally, Del Code Ann Tit 8, \$141(a) (2001); Model Bus Corp Act, \$8.01(b); Paramount Communications, Inc v Time, Inc, 571 A2d 1140, 1154 (Del 1989); Charlestown Boot \& Shoe Co v Dunsmore, 60 NH 85, 87 (1880). 
right to sell their shares. ${ }^{70}$ Company law is considered to grant the right to vote on the appointment and removal of directors. ${ }^{71}$ Many scholars would also point to the notion that shareholders have the nearly exclusive right to initiate legal proceedings for breaches of directors' duties. ${ }^{72}$ Yet in practice such a perspective pays insufficient attention to the argument that the exercise of these corporate governance rights is seriously curtailed by significant practical impediments, ${ }^{73}$ or indeed that rights themselves are dialectical to the extent that they contain intrinsic power while simultaneously reinforcing the institutions and structures from where those rights emanate. ${ }^{74}$

We are subsequently left to infer within this legal vacuum that the current dominance of the shareholder value principle in domestic and international corporate capitalism can be attributed to exogenous and entrenched highly liquid market environments, as well as institutional shareholder expectations, which have inculcated a range of prevalent shareholder-orientated managerial norms and practices from the late 1970 s onwards. ${ }^{75}$ In contrast to the 1930s, when Berle and Means were recording the dispersal of ownership among a myriad of small, passive investors, which undermined the power and influence of financial interests, ${ }^{76}$ recent decades under the direction of a neoliberal agenda have witnessed the gain of momentum for a reconcentration of share ownership. ${ }^{77}$ The growth in newer forms of concentration of capital, in particular the private equity funds financed by investment banks, asset management firms, pension and mutual funds, and hedge funds, as well as the increase in informal shareholder activism which accompanied this development, has precipitated a radical shift in the balance of power within companies and contributed to a dramatic change in corporate culture. With significance amounts of equity ownership, institutional investors could not sell without driving the share price down, so the threat to sell or 'voice' becomes the better option than 'exit', and this is, in essence, the non-

70 Under the corporate law of the UK and US state law, the usual rule is that shares of stock are freely transferable. Corporate legislations do not see the need to specify the basic right of property, but it is implicit in statutory provisions regulating restrictions on share transfer.

71 Companies Act 2006, s 168. The corresponding US provision is Delaware General Corporation Law, \$141(k).

72 In many common law jurisdictions, provision is made in companies legislation for the bringing of derivative actions: Companies Act 2006, ss 260-4 (UK); Canada Business Corporations Act 1985, s 239 (Canada); Corporations Act 2001, pt 2F1A (Australia); Companies Act, s 216A (Singapore); Companies Act 1993, s 165 (New Zealand); and Companies Ordinance, s 168BC (Hong Kong). The US retains a common law derivative action, the paternity of which can be traced back to Robinson v Smith, 3 Paige Ch 222 (NY 1832). But see J C Coffee Jr, 'Unstable Coalitions: Corporate Governance as a Multi-Player Game' 78 Georgetown Law Journal (1990) 1495, 1496.

73 A Keay, 'Company Directors Behaving Poorly: Disciplinary Options for Shareholders' (2007) Journal of Business Law 656.

74 D Attenborough, 'The Vacuous Concept of Shareholder Voting Rights' (2013) 14 European Business Organization Law Review 147, 166-72.

75 P Ireland, 'Financialization and Corporate Governance' (2009) 60 Northern Ireland Law Quarterly 1, 21, observing that 'it is ... financial markets, under whose constant shadow executives now work, that have been the key mechanism through which financial imperatives have been imposed on corporations and their executives'.

76 A Berle and G Means, The Modern Corporation and Private Property (New Brunswick 1932). This was simply an extension of Berle's earlier studies in the law of corporate finance. See A Berle, Studies in the Law of Corporation Finance (Callaghan \& Co 1928). On the commonalities with the UK, see R La Porta, F Lopez-de-Silanes and A Shleifer, 'Corporate Ownership around the World' (1999) 54 Journal of Finance 471, 491-8; R La Porta, 'Law and Finance' (1998) 106 Journal of Political Economy 1113, 1147.

77 P L Davies, 'Institutional Investors in the United Kingdom' in D D Prentice and P R J Holland (eds), Contemporary Issues in Corporate Governance (Clarendon Press 1993) 70, proclaiming that: ' $[t]$ he dominance by the financial institutions of the market in the ordinary (equity) shares of UK companies is a well-established fact'. See also, B R Cheffins, 'The Undermining of UK Corporate Governance(?)' (2013) 33 Oxford Journal of Legal Studies 503. 
legal power as a social phenomenon we speak of that permits modern investors to pressure managers for increased, often short-term, returns. ${ }^{78}$ It is precisely this allocation of property (rather than voting) rights which legal systems confer on the owners of equity capital through systems of corporate governance as well as the highly concentrated nature of ownership that, in a critical sense, is an expression of the relative power of the bearer. ${ }^{79}$ At the same time, however, there have been important changes in the ways in which corporate executives are remunerated - the rise of 'bonding mechanisms' for company management such as executive share options and other performance-related (often shareprice-related) remuneration - which have realigned their interests and brought them much closer to those of shareholders. ${ }^{80}$ With corporate strategies increasingly sensitive to investor expectations, the maximisation of shareholder value has emerged as the overriding corporate goal. These non-legal drivers, as well as an academic and practitioner consensus narrative, have become an underlying, and illegitimate, source of law. It is against this ideological framework, it is argued, that any examination of the English legislative reform process for directors' duties must take place.

\section{The rule in section 172}

Since the end of the 1990s, the volume of writing on corporate governance as a subject of legal and social-scientific ${ }^{81}$ enquiry has proliferated and, in consequence, the critical concept has now become well-entrenched as academic and regulatory shorthand. ${ }^{82}$ It is sometimes explicitly, but most of the time implicitly, a conduit through which theoretical debates, directly affecting other disciplines such as economics, politics and sociology, are conducted concerning the inter-relationship between corporate constituents. ${ }^{83}$ The importance of this particular aspect of company law is exemplified by the sentiments expressed in a law review article published in 1964 that 'the concern may be said to be with the political position of the modern corporation, the role it is and should be playing in the distribution and

78 On the idea that corporate managers are prone to operate in accordance with short-term time horizons, see M Moore and E Walker-Arnott, 'An Alternative View of Corporate Short-Termism' (2014) 41(3) Journal of Law and Society 416. For a useful US example, see M Porter, 'Capital Disadvantage: America's Failing Capital Investment System’ (1992) 65 Harvard Business Review 65.

79 Jones (n 39) 18, arguing convincingly that: 'as financial markets have integrated on a transnational basis and the composition of equity holders has shifted from individual to institutional investors, finance capital has become a dominant force in the international community'. See also, H Laski, A Grammar of Politics (Allen \& Unwin 1925) $175 \mathrm{ff}$.

80 M Jensen and W Meckling, 'Theory of the Firm: Managerial Behavior, Agency Costs and Ownership Structure' (1976) 3 Journal of Financial Economics 305, 308.

81 For an interesting perspective of whether or not the law itself and methods associated with the discipline is truly a social science, see G Samuel, 'Is Law Really a Social Science? A View from Comparative Law' (2008) 67(2) Cambridge Law Journal 288.

82 Although Brian Cheffins observes that corporate governance only acquired a strong international dimension in the 1990s, but the developments were identifiable as far back as the 1970s in America. See B R Cheffins, 'The History of Corporate Governance' in The Oxford Handbook of Corporate Governance (OUP 2013) ch 3. But see, Keay (n 54) 1, who suggests that the term has been an important one in the commercial world as far back as the birth of the limited liability company; D D Prentice, 'Some Aspects of the Corporate Governance Debate' in Prentice and Holland (n 77) 26, noting, equally, that: '[t]his is not a new debate; concerns about corporate governance have existed almost since the joint-stock company in its present form'.

83 Moore and Rebérioux (n 7) 85, observing that: "[a]lthough the term "corporate governance" literally applies to any incorporated entity, corporate governance scholars tend to be primarily concerned with "public" or listed corporate entities, whose securities are traded on regulated liquid investment markets'. 
enjoyment of a great variety of the values in which the community is interested'. ${ }^{84}$ Of course, intellectual endeavour surrounding the scope, form and content of directors' general duties and how directors govern the corporate body is perhaps one of the oldest issues in company law and corporate governance. Indeed, it is also the issue that has proved most intricate and difficult. These are the duties which company law applies directly to the members of the board as to limits within which they should exercise their powers. Prior to the Companies Act 2006, English company law instantiated these duties through a combination of common law rules and equitable principles that can be traced back to the nineteenth century. We have already seen that the absence of clarity in the formation of the term 'interests of the company' or any sort of consensus narrative in the courts, unsurprisingly, meant that these rules were thought by many to be too incoherent, sprawling and anachronistic. ${ }^{85}$

The Law Commission was subsequently asked to consider the state of the law and to make recommendations. It did so carefully, concluding that the pre-existing substantive law was too opaque and unclear. It ultimately recommended that it was necessary for only partial (i.e. non-exhaustive) codification of the settled directors' general duties, leaving the courts to prospectively develop any unsettled or new duties. The advantages of this approach were seen to lie in its flexibility. Following on from this report, the administratively independent Company Law Review ${ }^{86}$ supported codification and proposed an exhaustive legislative restatement of duties to entirely replace the general law. The Company Law Review's recommendation that reform in the way of full (i.e. exhaustive) codification was preferable (but drafted at a sufficiently high level of generality designed to enhance flexibility) was accepted by the government and reforms were enacted in ch 2 of pt 10 of the Companies Act 2006 that became operative on 1 October 2007 and 6 April 2008. ${ }^{87}$ It is apposite to note that the transfer of directors' general duties from their existing common law and equitable realm into the 'arguably more rigid and politically reactive territory of statutory law' 88 was an enduring and daunting one, beginning with a debate in the mid-1920s, with the idea being rejected entirely on the basis that it would be a hopeless task. In the 1960s the Jenkins Committee, despite concerns that it was not possible to provide specific definitions of the duties of directors in legislation, did in fact promulgate some form of codification. But there was no follow-up on this recommendation. Deidre Ahern thus captures in this regard the significance of the present legislative spread in English company law, observing that 'the

84 H G Manne, 'The "Higher Criticism” of the Modern Corporation' (1962) 62(3) Columbia Law Review 399, 399. See also, J Farrar, 'Corporate Governance, Business Judgement and the Professionalism of Directors' (1993) 5 Corporate and Business Law Journal 1, 1, remarking on 'the legitimacy of corporate power, corporate accountability and standards by which the corporation is to be governed and by whom'.

85 Davies and Worthington (n 68) 502, noting '[t] he substantial corpus of learning on the nature and scope of these general fiduciary or equitable duties and duties of skill and care [my emphasis added]'.

86 Company Law Review, Strategic Framework (n 5); Company Law Review, Modern Company Law for a Competitive Economy: Developing the Framework (Department for Trade and Industry 2000); Company Law Review, Modern Company Law for a Competitive Economy: Completing the Structure (Department for Trade and Industry 2000); Company Law Review, Modern Company Law for a Competitive Economy: Final Report (Department for Trade and Industry 2000).

87 D Ahern, 'Directors' Duties, Dry Ink and the Accessibility Agenda' [2012] Law Quarterly Review 114, 114, raising doubt over whether full codification has in practice been achieved, the author notes that the new statutory statement of the duties of directors represents 'a partial codification of the rich heritage of preexisting equitable and common law principles [my emphasis added]'. See also Davies and Worthington (n 68) 503, remarking that: '[i]n the end, and despite the initial behavioural premises, the Act probably comes closer to the Law Commissions' view'.

88 Moore (n 61) 190 (and accompanying footnotes). 
transfer of directors' duties to a legislative scheme qualified as a major landmark in the evolutionary history of the duties' ${ }^{89}$

The most conspicuous feature of this legislative reform project is the reformulated core duty of loyalty found in s 172 of the 2006 Act. ${ }^{90}$ The duty of loyalty is the fiduciary duty imposed on directors and trustees requiring them to prefer their duty to the company instead of intentionally exercising their management discretion to favour their own personal interests. Section 172 constitutes an attempted codification of the aforementioned formerly imprecise judicial construct of the interests of the company. It forms one of several streamlined and clarified duties that are imposed on company directors; ${ }^{91}$ indeed, the argument can be advanced that it is the governing section for determining the propriety of directorial conduct under all the subsequent duties. ${ }^{92}$ Sarah Worthington has, equally, described the duty of loyalty as defining the process of a director's general decision-making rather than any given resulting decision. ${ }^{93}$ For many, s 172 represents more than a consolidation or simplification of the pre-2006 Act common law rules; there were some perceived subtle changes to the rules ${ }^{94}$ and Parliament legally mandated a neologism of an enlightened shareholder value ${ }^{95}$ approach to the duty of loyalty. The Company Law Review defined enlightened shareholder value as an obligation on directors to: 'achieve the success of the company for the benefit of the shareholders by taking proper account of all the relevant considerations for that purpose' and this involves taking 'a proper balanced view of the short and long term; the need to sustain effective ongoing relationships with employees, customers, suppliers and others' as well as to 'consider the impact of its operations on the community and the environment'. ${ }^{96}$

Enlightened shareholder value is thus the idea that long-term business success depends on regard for the interests of all who contribute to and are affected by the myriad of corporate endeavours and is purported to represent an alternative to a narrow conception of orthodox notions of shareholder value. ${ }^{97}$ This has been referred to as moderating the

89 Ahern (n 87) 114.

90 Companies Act 2006, s 172(1) provides that: '[a] director of a company must act in the way he considers, in good faith, would be most likely to promote the success of the company for the benefit of its members as a whole, and in doing so have regard (amongst other matters) to- (a) the likely consequences of any decision in the long term, (b) the interests of the company's employees, (c) the need to foster the company's business relationships with suppliers, customers and others, (d) the impact of the company's operations on the community and the environment, (e) the desirability of the company maintaining a reputation for high standards of business conduct, and (f) the need to act fairly as between members of the company'.

91 Companies Act 2006, ss 170-7. This statement sets out principles relating to independence of judgement, conflicts of interest, fairness, care, skill and diligence etc. For a detailed discussion of the duties, see A Keay, Directors' Duties (Jordans 2009).

92 Shepherds Investments Ltd v Walters [2006] EWHC 836, [106].

93 Worthington (n 5) 447.

94 It should be noted, however, that two of only four cases that have mentioned the provision (outside of consideration of the derivative action provisions) have stated that it sets out the pre-existing law on the subject. See Re West Coast Capital (LIOS) Ltd [2008] CSOH 72; 2008 Scot (D) 16/5 (Outer House, Court of Sessions, Lord Glennie) [21]; Cobden Investments Ltd v RWM Landport Ltd [2008] EWHC 2810 (Ch).

95 The provision is attached to a narrative reporting obligation in $\mathrm{s} 417$, which requires directors of certain companies to produce a business review document to inform shareholders how they have performed these duties. See C Villiers, 'Narrative Reporting and Enlightened Shareholder Value under the Companies Act 2006' in J Loughrey (ed), Directors' Duties and Shareholder Litigation in the Wake of the Financial Crisis (Edward Elgar 2012) 97.

96 Company Law Review, Developing the Framework (n 86) para. 2.11.

97 On the similarities with the construct of corporate social responsibility, see D J Wood, 'Corporate Social Performance Revisited' (1991) 16 Academy Management Review 691, 695, stating that 'the basic idea of corporate social responsibility is that business and society are interwoven rather than distinct entities'. 
stricter aspects of capitalism. ${ }^{98}$ However, it is generally acknowledged that many open issues remain in respect of what is its most persuasive reading of the statutory duty of loyalty. This sentiment has been echoed in a recent law review article by Alan Dignam and Michael Galanis, who have remarked that 'directors' fiduciary obligations . . . have remained sufficiently vague so as to create a wide management discretion with regard to major decisions. ${ }^{99}$ Section 172 sets out, arguably, the most controversial and challenging duty that has been introduced in the Act. That the provision can be described in this way is demonstrated by the fact that it probably generated more substantial debate in Parliament than any other provision contained in the whole of the Act. ${ }^{100}$ It has similarly produced voluminous scholarly writings leading up to (and going beyond) the legislation receiving royal assent.

The new statutory formulation of the fundamental duty of loyalty owed by directors comprises two significant aspects. First, s 172(1) begins by stating that a 'director must act in the way he considers, in good faith, would be most likely to promote the success of the company for the benefit of its members as a whole'. This clearly reflects, while using different wording, the elemental principle that it is for the directors to decide in good faith what they perceive to be beneficial for the interests of the company and this is ostensibly animated by the company's organisational aims and objectives. ${ }^{101}$ There are at first sight aspects of this subjective duty that are similar to what has been stated in earlier case law. For example, in Aberdeen Railway Co v Blaikie Brothers, ${ }^{102}$ Lord Cranworth LC said that "[a] corporate body can only act by agents, and it is of course the duty of those agents [the directors] so to act as best to promote the interests of the corporation whose affairs they are conducting. ${ }^{103}$ A century later Lord Greene MR in Smith v Fawcett Ltd 104 noted that directors 'must exercise their discretion bona fide in what they consider . . . is in the interests of the company'. ${ }^{105}$ On this reading, it is likely that the courts will be able to remain highly receptive to the case law that addressed the precursor duty. This supposition is supported by the fact that two post-2006 Act cases have said that the pre-existing law on the duty of loyalty will be applied in dealing with cases initiated pursuant to s 172.106 For example, Warren $\mathrm{J}$ in Cobden Investments $L t d^{107}$ said that the common law and statutory duty 'come to the same thing with the modern formulation giving a more readily understood definition of the scope of the duty'. 108 To this extent, directors should take from the new provision the simple, enduring maxim that the court will show deference to the exercise of the board's contractually delegated managerial authority as to what was best calculated to serve the

98 Keay (n 54) 287.

99 Dignam and Galanis (n 33) 224.

100 Keay (n 54) 85.

101 This position is reinforced in Companies Act 2006, s 170(1), which lays down the principle that: '[t]he general duties specified in sections 171 to 177 are owed by a director of a company to the company'.

102 Aberdeen Railway Co v Blaikie Brothers (1854) 1 Macq 461. See also, Scottish Wholesale Society Ltd v Meyer [1959] AC 324, 367, per Lord Denning, saying that the duty of directors 'was to do their best to promote its business and to act with complete good faith towards it'.

103 Aberdeen Railway Co v Blaikie Brothers (n 102), 471 HL (Sc) per Lord Cranworth LC.

104 Smith v Fawcett Ltd [1942] Ch 304.

105 Ibid 306.

106 Re West Coast Capital (LIOS) Ltd (n 94); Cobden Investments Ltd v RWM Landport Ltd (n 94).

107 Cobden Investments Ltd v RWM Landport Ltd (n 94) [52].

108 Ibid. 
company's overall welfare in any given instance, although this is subject to the overriding jurisdiction of the courts to assess objectively the conduct in question. ${ }^{109}$

However, this is not the full picture of the formulation and content of the director's reformulated duty of loyalty. More fundamental still, the wording of s 172, in fact, signals a departure from this orthodox formulation of the duty that it effectively succeeds and introduces a different managerial obligation as a touchstone for corporate governance. As we have seen, the pre-2006 Act common law rules on the issue of to whom directors owed their loyalty has for more than 150 years been associated with the interests of the company as an entity but not directly to any individual shareholders or other persons. This indeterminacy of the common law has allowed the courts, save for selective deference to private ordering, to resist the temptation to ascribe judicially determined interests or goals to the company. ${ }^{110}$ Section 172 challenges this classic doctrinal logic to the extent that it "juridifies and therefore concretises the "interests of the company" (terminology which is omitted from the statutory formulation), by defining the corporate objective explicitly in terms of the success of the company for the benefit of its shareholders as a whole [my emphasis added]'. ${ }^{111}$ From one point of view, the retention of the 'interests of the company' is important primarily in relation to the enforcement of directors' duties. ${ }^{112}$ From another point of view, this means that, in respect of defining the process or method of a director's general decision-making, we see clearly that the Act mandates shareholder prerogative as the core value of UK corporate governance. The provision thus puts the expressed primacy of shareholders on a legislative footing for the first time in English company law. David Kershaw has raised the inference that '[o]ne might ask whether an enlightened shareholder value approach is any different than an approach that simply focuses on shareholder value'. ${ }^{113}$ The answer appears to be that there is no difference when viewed through the prism of hegemonic neoliberal thought. It is submitted that Carrie Bradshaw is correct in her remarks that 'enlightened shareholder value is not a challenge to the exclusivity of shareholders', ${ }^{114}$ but instead 'provides a new strength to shareholder exclusivity by way of an unambiguous statement in legislation [my emphasis added]'. ${ }^{115}$ It is argued that through this lens the most representative reading of the provision can be identified.

To be sure, careful attention to the wording of the Act and the interpretation it supports has, as is the case with s 172, generated a critical scholarly narrative of the effects of law reform that represents radical change to an avowedly narrower duty of loyalty and not continuity with respect to what directors are actually expected to do. ${ }^{116}$ This change is a

109 Howard Smith Ltd v Ampol Petroleum Ltd [1974] AC 82, PC; Regentcrest plc v Cohen [2001] 2 BCLC 80; Item Software (UK) Ltd v Fassibi [2005] 2 BCLC 91.

110 On the time-honoured highly subjective nature of the traditional judicial test, see Moore (n 61) 153-4.

111 Ibid 192.

112 Davies and Worthington (n 68) 506. It follows from the fact that duties are said to be owed to the company that, as with the law as it has been in the past, only the company can enforce them. However, pt 11 of the Act permits members, through the derivative claim, to enforce the duties, in certain cases, on behalf of the company.

113 Kershaw (n 68) 379.

114 C Bradshaw, 'The Environmental Business Case and Unenlightened Shareholder Value' (2013) 33(1) Legal Studies 141, 156.

115 Ibid.

116 Moore (n 61) 193-4; D Millon, 'Enlightened Shareholder Value, Social Responsibility and the Redefinition of Corporate Purpose Without Law' in P M Vasudev and S Watson (eds), Corporate Governance after the Financial Crisis (Edward Elgar 2012) 68; Bruner (n 66) 34-5; Bradshaw (n 114) 155-6. Although on the continuing ambiguity of s 172's application, see Keay (n 54) 86. Recent case law decisions appear to contain a confused interpretation of the relationship between the pre-existing substantive common law and the new legislative duty of loyalty. See Re West Coast Capital (LIOS) Ltd (n 94); Cobden Investments Ltd v RWM Landport Ltd (n 94). 
particularly acute problem in the context of a legislative reform project because it occurred despite the absence of a legal and formal mandate to this effect in the area of directors' general duties. A compelling case can be made that the shareholder-oriented conception of the company was formed not from the pre-existing substantive law itself, but instead through the prevalent short-term, stock-market-based pressures of finance, the neoliberal logic of which has assisted the legislative imperative of the shareholder value principle in English company law. It is suggested that this is what David Millon, writing in 2012, was referring to when he spoke astutely of 'the redefinition of the corporate purpose without law'. ${ }^{117}$ But the fact of the matter is that major policy decisions and law-making 'are the product of many institutional forces'. ${ }^{118}$ It is argued, as we have seen, that this shareholderoriented conception of the company is ultimately a reflection of the 'seismic changes which took place in the corporate world during the neoliberal counter-revolution' from the late 1970 s onwards, ${ }^{119}$ which have given rise to the expectations of investors increasingly finding expression in legal determinants as well as extra-legal drivers that actually shape management behaviour. ${ }^{120}$

For some time, the alleged defects of English law have received a great deal more attention than its merits. It is therefore easy to overlook real achievements, among which one of the more conspicuous is that the 2006 Act does not, at the very least, continue on the false assumption that the paradigm company in English law is a large, publicly quoted, for-profit business. ${ }^{121}$ A company can be established for a myriad of specific purposes or even lengths of time; large British multinational banking and financial services companies, public teaching and research universities, charitable organisations, joint ventures, holding companies, clubs and societies, and many, many more are incorporated under, and have legal existence, by virtue of the companies' legislation. These are deliberately extreme examples chosen to make an important point. The obligation, as part of the duty of loyalty, to promote the success of the company for the benefit of its shareholders as a whole means that English company law provides an 'adjectival' principle which is capable of governing how a diversity of possible corporate constitutions may lawfully and legitimately be pursued. In particular, the provision uses such an opaque term as 'success' because it is a concept which necessarily requires a referent to provide it with a whole meaning. This referent is, perhaps unexpectedly, not prescribed through English companies' legislation as such, but is instead supplied from the shareholders as market participants (e.g. the company's constitution, shareholders' decisions and so on) in any given corporate economy. As the Attorney General (as he was then) Lord Goldsmith stated: '[s]uccess means what the [shareholders] collectively want the company to achieve. For a commercial company, success will usually mean . . . increase in value. For . . charities and community interest companies, it will mean the attainment of the objectives for which the company has been established.'122

An exclusively shareholder-oriented conception of the company in the nature of things thus means that the law has created, and then extracted itself from, a self-sustaining, market-driven ecosystem in which it is essentially for the shareholders of the company to

117 Millon (n 116) 68.

118 J A C Hetherington, 'Fact and Legal Theory: Shareholders, Managers, and Corporate Social Responsibility' (1969) 21 Stanford Law Review 248, 292.

119 Ireland and Pillay (n 48) 78.

120 Ibid 91.

121 Lowry (n 2) 640, discussing the historical (in)applicability of English companies legislation to various types of corporate activity.

122 Lord Goldsmith, Lords Grand Committee, 6 February 2006, col 255. 
formulate the organisational aims they wish to achieve as well as having the authority to determine collectively whether these aims have been successfully met by the board. As pointed out earlier, this line of thinking is consistent with the Company Law Review's expressed presumption against interventionist legislation and in favour of facilitating markets. ${ }^{123} \mathrm{It}$ had, equally, limited its scope to law reform rather than concerning itself with wider ethical or managerial issues about the behaviour of participants in companies. ${ }^{124}$ The same basic logic finds its origins in an aforementioned argument that the state is not, as frequently posited under the rhetoric of neoliberalism, external or involuntarily relinquishing sovereignty to the market, but is a qualitatively different state that purposefully establishes and preserves through constant action an artificial institutional framework appropriate to such competitive practices. ${ }^{125}$ If markets do not exist, so the argument follows, then they must be created or reconfigured, by state action if necessary. But beyond these efforts the state should remove itself from the economy, including corporate affairs. Observing this, one cannot help submit that a not altogether unfair epilogue to this assessment is the important point that, while one simply cannot equate companies with trading at a profit, this is indeed the most common use of the corporate form. This, of course, means that success for commercial companies will typically involve an increase in the value of the company's shares, or at least the maximisation of the company's profits. It is in many ways odd that, during a period when the shareholder value principle and shareholder expectations, as well as managerial short-termism, are frequently asserted causes of many of the catastrophic ills of the global financial system over recent decades, ${ }^{126}$ yet under English company law the entrenching of financialisation and shareholder interests is now presented ex cathedra as a metric of corporate performance.

The second aspect of the duty is that, as a corollary of promoting the success of the company for the benefit of the members as a whole, an ancillary obligation is expressly imposed on corporate management to 'have regard (amongst other matters)' to the nonexhaustive factors and constituencies set out in sub-paragraphs (a)-(f). ${ }^{127}$ Under this approach, directors, while ultimately required to promote shareholder interests, must take into account an extensive list of internal and external factors when considering what promotes shareholder interests. This 'regard list' in s. 172 includes, but is not limited to, long-term consequences, employee interests, relations with suppliers, customers and others, impact on the community and environment, and the company's reputation for high standards and business conduct. The inclusion of these non-member interests might be seen as involving the development of sustainability, good relations with constituencies and

123 Company Law Review, Strategic Framework (n 6) paras 2.1-2.34.

124 Ibid para 5.1.2.

125 Harvey (n 12) 2. See also, Amable (n 34) 10.

126 R Tomasic, 'The Failure of Corporate Governance and the Limits of Law: British Banks and the Global Financial Crisis' in W Sun, J Stewart and D Pollard (eds), Corporate Governance and the Global Financial Crisis (CUP 2011) 50, submitting that ' $[\mathrm{t}$ ] he global financial crisis demonstrated the fragility of the widely accepted faith in prevailing corporate governance ideas and the adequacy of legal mechanisms that were available to buttress these ideas'; S Deakin, 'Corporate Governance and Financial Crisis in the Long Run' in Williams and Zumbansen (n 41) 30-5; Davies (n 77) 79, neatly summarising the argument that, 'enhancing shareholder pressure causes corporate management to take decisions that increase the company's revenues in the shortterm, but at the expense of its long-term profitability and competitiveness'.

127 Companies Act, s 172(1)(a)-(f) requires the directors to have regard to the following matters: (a) the likely consequences of any decision in the long term; (b) the interests of the company's employees; (c) the need to foster the company's business relationships with suppliers, customers and others; (d) the impact of the company's operations on the community and the environment; (e) the desirability of the company maintaining a reputation for high standards of business conduct and; (f) the need to act fairly as between members of the company. 
enhancing reputation, all of which might well lead to success for the company. ${ }^{128}$ This aspect is thus purported to engender the 'enlightened' element of the enlightened shareholder value approach preferred by the Company Law Review and the government. An inference that may be drawn from its inclusion in the Act is that it has the potential to displace the ideology of corporate performance measured solely and simplistically through maximising short-term shareholder value; those non-contractual expectations and cultural values, such as trust, social welfare and fairness, are important as well. ${ }^{129}$ This is, of course, bound up with the enduring and fundamental argument in corporate governance that the shareholders are not the only group whose well-being is affected by corporate decisions. ${ }^{130}$

Corporate academics and practitioners have fervently debated the best reading of this second aspect of the provision. At one end of the continuum, some have suggested optimistically that the introduction of stakeholder interests into the statutory vocabulary represents significant corporate legal movement involving change incorporating some form of broader stakeholder mandate. ${ }^{131}$ This is a view that is also informed by, and depends greatly upon, the reports of the Company Law Review and the ministerial statements made in Parliament during the legislative debates. Occupying the middle distance, we find limited support for the view that, while this aspect of the provision does not signal radical change to directors' general duties, it is going to be principally cultural or educational for corporate management in presenting stakeholder interests as part of a choice architecture in order to positively influence decision-making. It is a line of thinking which, in essence, frames this aspect of the duty as a form of 'nudge' regulation, which is a concept that has in recent years been promulgated by Richard Thaler and Cass Sunstein. ${ }^{132}$ At the other end of the spectrum, there has been a lot of derision over the perceived failure on the part of the government to fulfil a commitment or responsibility to redefine a more nuanced conception of the company as a social institution rather than as a purely private enterprise. In this way, any reference to non-member interests is viewed as a little more than a rhetorical flourish. Dan Prentice has said of a social responsibility on the part of companies at a general level that ' $[\mathrm{o}]$ ne must concede . . . that these statements have often appeared aspirational in their thrust and have not provided a detailed blueprint for concrete action'. ${ }^{133}$

It is thus fair to suggest that the issue of how enlightened shareholder value relates to, and impacts on, corporate governance has atomised the opinions of legal academics and practitioners. What is perhaps more fundamental is that the generalised inability to conceptualise and find answers to the particular use of statutory language indicates legislative ambiguity or obscurity as to the precise meaning of this aspect of the duty. A

128 Keay (n 54) 111.

129 See, for example, D Attenborough, 'Giving Purpose to the Corporate Purpose Debate: An Equitable Maximisation and Viability Principle' (2012) 32 Legal Studies 4; Blair and Stout (n 55); L Mitchell, 'Fairness and Trust in Corporate Law' (1993) 43 Duke Law Journal 425.

130 The Company Law Review termed this the 'scope' of company law. See Strategic Framework (n 5) 33-46.

131 A Mickels, 'Beyond Corporate Social Responsibility: Reconciling the Ideals of a For-Benefit Corporation with Director Fiduciary Duties in the US and Europe' (2009) 32 Hastings International and Comparative Law Review 271, 293; S Kiarie, 'At a Crossroads: Shareholder Value, Stakeholder Value and Enlightened Shareholder Value: Which Road Should the United Kingdom Take?' (2006) 17 International Company and Commercial Law Review 329; C Williams and J Conley, 'An Emerging Third Way? The Erosion of the AngloAmerican Shareholder Value Construct' (2005) 28 Cornell International Law Journal 493, 499; L Roach, 'The Legal Model of the Company and the Company Law Review' (2005) 26 Company Lawyer 98.

132 R H Thaler and C R Sunstein, Nudge: Improving Decisions about Health, Wealth and Happiness (Penguin 2009). For a more company law-oriented account, see L A Stout, Cultivating Conscience: How Good Laws Make Good People (Princeton University Press 2010).

133 D D Prentice, 'Some Aspects of the Corporate Governance Debate' in Prentice and Holland (n 77) 26. 
problem in statutory construction can seriously trouble the courts when there is a contest between probabilities of meaning. There is, equally, an anxiety relating to whether the drafting of s 172 results in a duty likely to be better understood by directors than the preexisting substantive common law so that compliance can be achieved. This is despite the fact that certainty, accessibility and simplification were strategic Company Law Review objectives. Principles of statutory interpretation allow the court, where the meaning of legislation is ambiguous or obscure, to resort in limited circumstances to ministerial statements made at the time of the passage of legislation. ${ }^{134}$ However, the nature of the legislative process means that treating statements of ministers in Parliament as probative evidence of parliamentary intention is controversial. ${ }^{135}$ Pursuant to the rule in Pepper $v$ Hart, what the executive intended, as stated in Parliament, may be relied on as an interpretive aid where that record of intention is so 'clear and unequivocal' that it would 'almost certainly settle the matter immediately one way or the other'. ${ }^{136}$ The parliamentary statements and material on s 172 do not satisfy this threshold condition and should not therefore be considered by a court. The problem is compounded by the omission to explain precisely where the restatement diverges from settled jurisprudence surrounding the duty of loyalty.

It is submitted, however, that the meaning of the second aspect of the restated duty of loyalty and therefore the duty itself is patently clear and unambiguous. As already discussed, corporate management has an ultimate responsibility under the Act to promote the success of the company for the concretised and exclusive benefit of the shareholders as a whole. This, of course, at least insofar as ordinary commercial companies are concerned, will involve an increase in the value of the company's shares, or at least the maximisation of the company's profits. This is the imperative of private ownership of capital: to maximise returns by reducing costs and ensuring maximum fluidity to seek out the highest performers over the short term. ${ }^{137}$ The formalised attendant 'regard list' of various socio-economic factors, as a practical matter, is expressly unequal to this principal objective, and nonshareholder interests are valued only instrumentally to achieving this economicindividualistic objective rather than as a substantive programme of action to address real concerns based on any ethical or intrinsic value. ${ }^{138}$ Acting in a socially responsible manner is thus conflated and confused with rational economic behaviour. The provision, at the very most, might be said to educate or 'nudge' corporate management to assume more unselfish, ethical behaviour during the relentless focus on satisfying claims of private property ownership. But it is a 'fallacious assumption that as a matter of fact there is no conflict between shareholder value and wider socially responsible corporate activity'. ${ }^{139}$ It is, equally,

$134 \mathrm{~W}$ Twining and D Miers, How to Do Things with Rules (CUP 2010) 257-67.

135 D Kershaw, 'The Rule in Foss v Harbottle is Dead; Long Live the Rule in Foss v Harbottle' LSE Law, Society and Economy Working Paper 5/2013 (London School of Economics 2013) 32-33 <www.lse.ac.uk/collections/law/wps/WPS2013-05_Kershaw.pdf> accessed 21 October 2014.

136 Warner v Metropolitan Police Commissioner [1969] 2 AC 256, 279, per Lord Reid.

137 For a recent sophisticated argument along these lines, see Talbot (n 10).

138 Jones (n 67) 165, observing that instrumental arguments in favour of socio-economic interests are based on 'some kind of rational calculation that socially responsible behaviour will benefit the individual company and business as a whole, at least over the long term'.

139 L Talbot, Critical Company Law (Routledge 2008) 183. See also, Banerjee (n 39) 64; D M Branson, 'Corporate Governance "Reform” and the New Corporate Social Responsibility' (2001) 62 University of Pittsburgh Law Review 605, 630ff; Jones (n 39) 28, making the pertinent point that 'instructing a manager that he or she should behave in a socially responsible manner because it is the morally correct thing to do, despite the fact that such behaviour may be directly counterproductive to the manager's career, cannot be expected to hold much water in a world that is increasingly commodified, rationalised, and secular. In any organization, particularly a for-profit one, all resource allocation decisions must be justified in terms of some kind of positive return to the organization.' 
impermissible for non-shareholder constituencies to have legal standing to enforce any possible breach of failing to have regard for their interests under the derivative action in pt 11 of the 2006 Act. Enforcement of the duty is limited to the board of directors, a majority of shareholders, a minority of shareholders via derivative claims under pt 11 of the Act, and liquidators acting on behalf of an insolvent company. ${ }^{140}$ From this perspective, the purported enlightened or progressive bent of the restated duty of loyalty can thus be likened without any great inaccuracy to the emperor's new clothes. The 'enlightened' discourse simply obfuscates the essential forces driving business activity, as well as the pressures to which companies and decision-makers are subjected.

This conclusion, as things stand today, is to be expected within the political project of neoliberalism and the highly financialised, shareholder-oriented structures of corporate governance. The enlightened shareholder value principle, it is argued, is responsible for distorting much of the thinking about company law reform in recent years. This need not be the case. Despite its emancipatory rhetoric, discourses of broader social concerns are defined typically by narrow business interests and serve to curtail interests of nonshareholders. ${ }^{141}$ As we have seen, the principle does nothing to dislodge the view that the objective of a company's business is the pursuit of shareholder interests because it is essentially oriented toward system management rather than system negation. It is, and purports to be, only a general ideological adjunct that provides a visible legitimating narrative to the dominance of an exclusive focus on shareholder value. ${ }^{142}$ While relegitimising the shareholder-oriented paradigm through the artful manipulation of legal doctrine, the perceived formalised legislative integration of non-shareholder interests into management's calculus also serves the imperatives of capital accumulation through coopting or marginalising the more excessive socio-economic demands of these stakeholders. ${ }^{143}$ Indeed, under the logic and language of neoliberalism, enlightened shareholder value reflects a rarely acknowledged, yet fundamental perspective on the increasing misalignment between the powers of private ownership claims and socioeconomic interests that has in recent decades found expression politically, economically and, of course, legally. ${ }^{144}$ Perhaps in this regard the principle should be seen not as the invisible garments of a powerful sovereign ruler, but as a wolf in sheep's clothing - an efficiently distributive, malignant thought collective that is partially concealed by a symbolic, kinder and gentler representation.

\section{Conclusion}

This article may be viewed throughout as simply an illustration of just how a particular configuration of institutional and political-economic elements shape the resolution of nearly every issue of law-making as well as one's thinking about how political process

140 Companies Act, ss 260-4. See also, Moore (n 61) 192-3, referring to 'the dual status of shareholders both as the exclusive ultimate beneficiary of the duty, and the sole permissible derivative claimant group in respect of it'.

141 Banerjee (n 39) 52.

142 N J Mitchell, The Generous Corporation: A Political Analysis of Economic Power (Yale University Press 1989) 52.

143 Banerjee (n 39) 73, asserting that 'stakeholder relations are systematised and controlled by the imperatives of capital accumulation'; Jones (39) 9, discussing the 'accumulation and rationalization processes, which together constitute the core of capitalist political economy'.

144 Ireland and Pillay ( $\mathrm{n}$ 48) 91. The authors note that from the 1970s onwards the expectations of investors have achieved almost hegemonic dominance in hard law and quasi-legal forms. In the pursuit of a shareholderoriented conception of the company there has been, to varying degrees, a steady abrogation of stakeholder interests. At the same time, the interests of non-shareholder constituencies are being co-opted into 'soft' law or other non-legal instruments which either lack binding force altogether or whose binding force is noticeably weaker than that usually associated with 'hard' law. 
operates and law-making generally. Implicit in this article is the argument that previous writings on the reformulated duty of loyalty have so far failed to systematically address the persistent ideological determinants of companies organised for profit to pursue purposively those socio-economic ends that conflict with the presumptive logic of classical economics. The analysis of the reasserted power of finance, the neoliberal logic and language of which has repositioned the shareholder at centre stage, clearly shows us that current corporate governance structures, theoretically, empirically and normatively, dissolve any management objective other than shareholder value. The neoliberal worldview is, therefore, antagonistic to any purported ethic of the company as a social institution rather than a private enterprise. We have seen, unexpectedly, that the pre-existing substantive common law, as a practical matter and within the limited range of cases pertinent to this article, probably provided no substantial statutory or judicial authority to convincingly support this essential change to directors' general duties. However, the particular understanding of a politically determined and legally contingent phenomenon, it has been argued, helps to explain how the primacy of the exclusively shareholder-oriented conception of the company has now been enshrined in the 2006 Act. To many observers, the imperatives of private ownership of capital are to maximise returns by reducing costs and ensuring maximum fluidity to seek out the highest performers over the short term.

The global financial crisis has led to calls for greater corporate accountability and heightened controls over such industrial practices. Moreover, as already mentioned, classical economic imperatives leave no room in the management calculus to pursue socio-economic ends that conflict with the presumptive shareholder desire to maximise profits. Cast in this light, this perhaps distasteful, but definitely authoritative, principle of English company law is now in search of ideological legitimation or, at the very least, ideological elegance. The Company Law Review and UK government's concept of enlightened shareholder value purport to provide a solution in diverting management's attention to non-shareholder interests, including the environment, employees and local communities, as well as being seen as critical to generating long-term success. It is fair to suggest that the issue of what is the best reading of this aspect of the reformulated duty of loyalty has been subject to a mixed reception. What is perhaps more fundamental, the generalised inability to conceptualise and find answers to the particular use of statutory language would seem to indicate legislative ambiguity or obscurity as to the precise meaning of this aspect of the duty. However, the law, it is argued, is not opaque or indeterminate. The epistemologically flawed 'otherregarding' aspect of the duty is patently subordinated to the expressed primacy of shareholder interests. The duty, equally, provides no method of enforcement to these nonshareholder interests to enforce any potential breach of s 172. Instead, what the enlightened aspect of the duty does is provide an ideological adjunct that acts as a visible legitimating narrative to the dominance of an exclusive focus on shareholder value. 